\title{
KASTORIA "BLIND” ACTIVE FAULT: HAZARDOUS SEISMOGENIC FAULT OF THE NW GREECE
}

\author{
Ch. P. Metaxas ${ }^{1}$, N. S. Lalechos ${ }^{2}$ and S. N. Lalechos ${ }^{1}$ \\ ${ }^{1}$ Earthquake Planning and Protection Organization, Xanthou 32, Neo Psykhiko, 15451, Athens, \\ xmetaxas@oasp.gr,slalexos@oasp.gr \\ ${ }^{2}$ Former CEO of Public Petroleum Corporation of Greece (DEP - EKY)
}

\begin{abstract}
The Aliakmon river bed, as well as a series of certain parallel narrow grabens, striking NW-SE are filled with Neogene-Quaternary deposits; thus showing the existence of the covered, "blind", fault zone, which borders the Eastern edge of Meso-Hellenic Trench and passes in close vicinity to the

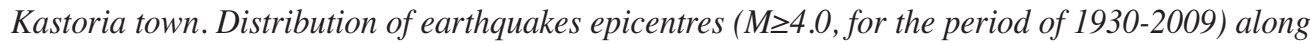
this segmented rupture zone, proves the existence at depth of an active seismogenic fault which has generated some strong earthquakes in the past: $1709, M=6.0 ; 1812, M=6.5$ and $1894, M=6.1$ ( 100-year Recurrence Time events). The calculations of Lapsed Rate characterizing the stage of the fault seismic cycle $(L R=115 \%)$ show that the active Kastoria fault could be in a pre-seismic stage of its seismic cycle. Applying the seismicity rates model (time-independent Gutenberg-Richter recurrence model) and using the fault seismicity parameters, obtained inside the fault influence zone, as input in EZ-FRISK ${ }^{\circledR}$ software, the Probabilistic Seismic Hazard Analysis has been carried out for the area of Kastoria town. The results show that calculated magnitude for event with 100year recurrence time is $\sim 6.1$, which correspond to the magnitude of three events, occurred at the fault during the last 300 years (corresponding average slip rate $.3 \mathrm{~mm} /$ year). As the calculated Hazard Curve shows, the event of that range could give ground shaking in the Kastoria town in the order of $0.625 \mathrm{~g}$ at the spectral period of $0.3 \mathrm{sec}$.
\end{abstract}

Key words: seismicity, "blind” seismogenic fault, seismic cycle, Probabilistic Seismic Hazard Analysis, ground shaking, Kastoria town, NW Greece.

\section{Introduction}

Vulnerability to earthquakes increases steadily as urbanization and development expand in areas that are prone to significant earthquakes. As the largest earthquakes of the past three decades have demonstrated, the development of large cities in high seismicity areas is often based on an insufficient knowledge of the local seismic hazard, a condition often deteriorated by the construction of seismically unsafe buildings and infrastructures (Boschi et al, 1996).

A "blind fault" should mean a fault plane with its upper limit under the surface of the earth. Blind faulting often induces intense damage owing to unexpected strong shaking. Such blind faults may be accompanied by distributed deformation, the amplitude of which is controlled by the width and the depth of the upper fault limit as well as the amount of the slip on the blind fault plane. Issues on geologically unexpected large earthquakes, wrong long-term forecasts and unknowable earthquakes 
are usually related to blind faults.

Papazachos \& Papazachou (2003) show the seismogenic fault associated with three historical strong surface earthquakes $(1709, \mathrm{M}=6.0 ; 1812, \mathrm{M}=6.5$ and $1894, \mathrm{M}=6.1)$ in close vicinity to the Kastoria town. No evidence of the surface traces of the fault has been mapped to date along the virtual projection of the fault line at the surface, neither as a result of instant (co-seismic) movements, nor as a result of long-time slip (aseismic creep) on the fault.

The objective of this paper is to define the location of the "blind" active seismogenic fault, to determine its tectonic and seismic activity characteristics as well as the present level of its hazard: seismicity potential, stage of seismic cycle, strong $(\mathrm{M}>6.0)$ earthquakes recurrence times and probable values of ground shaking that could be measured in Kastoria town (at the site of Kastoria Strong Motion Station of ITSAK, KAS1, 40.52N, 21.26E) in the case of seismic excitation on above mentioned "blind" active fault.

\section{Geological setting}

The Meso-Hellenic Trench constitutes a tertiary molassic graben, which has been individualized from middle Eocene. After the major tectonic phase (lower-middle Eocene) of the Pelagonian zone, which is overthrusting the Pindos zone, we observe a transgression in the upper Lutetian within the Pelagonian zone during its fracturing starting from Pindos zone where the sedimentation continues until the upper Eocene (Bizon et al., 1968). The graben formation continues during Oligocene (transgressive and discordant following tectonic movements) with tilting of the basin causing eastward transgressions (Heptakhorio series). Miocene appears to be transgressive on the boundaries of the basin (Pentalofo and Tsotyli series). Generally, the sedimentation is determined by a dissymmetric subsidence of the basin, resulting to tilting phenomena (I.F.P., 1966). The subsidence during Tertiary seems to be discontinuous with alternation of tectonic movements and erosion phases.

Two geodynamic models have been proposed in order to understand the paleogeographic and tectonic evolution of the Meso-Hellenic Trench; it is interpreted either as a back-arc basin (Papanikolaou et al, 1988) or as a piggy-back basin along the eastern flanks of a giant pop-up structure consisting of west-verging, foreland-propagating thrusts within the Apulian plate and of east-verging backthrusts within the Pelagonian plate (Doutsos et al, 1994).

The tectonics of Meso-Hellenic Trench is characterised by two longitudinal deep boundary faults (Fig. 1a) affecting the bedrock (i.e. the Pelagonian and Pindos zone). The fault limiting the NE boundary of the basin seems to increase its activity from Pliocene to date. Thus, Pliocene formations and Quaternary deposits are mainly outcropping along the NE boundary of the basin. In particular, the most recent movements of this normal fault seem to be intensive due to the fact that the western branch of Aliakmon river and all its downstream tributaries are flowing in the SW-NE direction, whereas the main river is thereafter flowing along the NE boundary of the basin, thus covering -with its deposits- the aforementioned fault and making it "blind". In more detail, the NE boundary is not constituted by a single normal fault, but by a series of successive narrow grabens (about 1-2 km wide) developed below the Aliakmon riverbed (Fig. 1b).

The area has been subjected to many deformational events during Alpine times, under both extensional and compressional regimes that reshaped the original structures and changed their relationships until Miocene. Since then, two main neotectonic extensional stages have occurred (Mercier et al., 1993; Mountrakis et al., 1995a); i) a NE-SW extension during upper Miocene - Pliocene that reactivated NW-SE mainly trending normal faults and ii) a NNW-SSE extension during Quaternary 


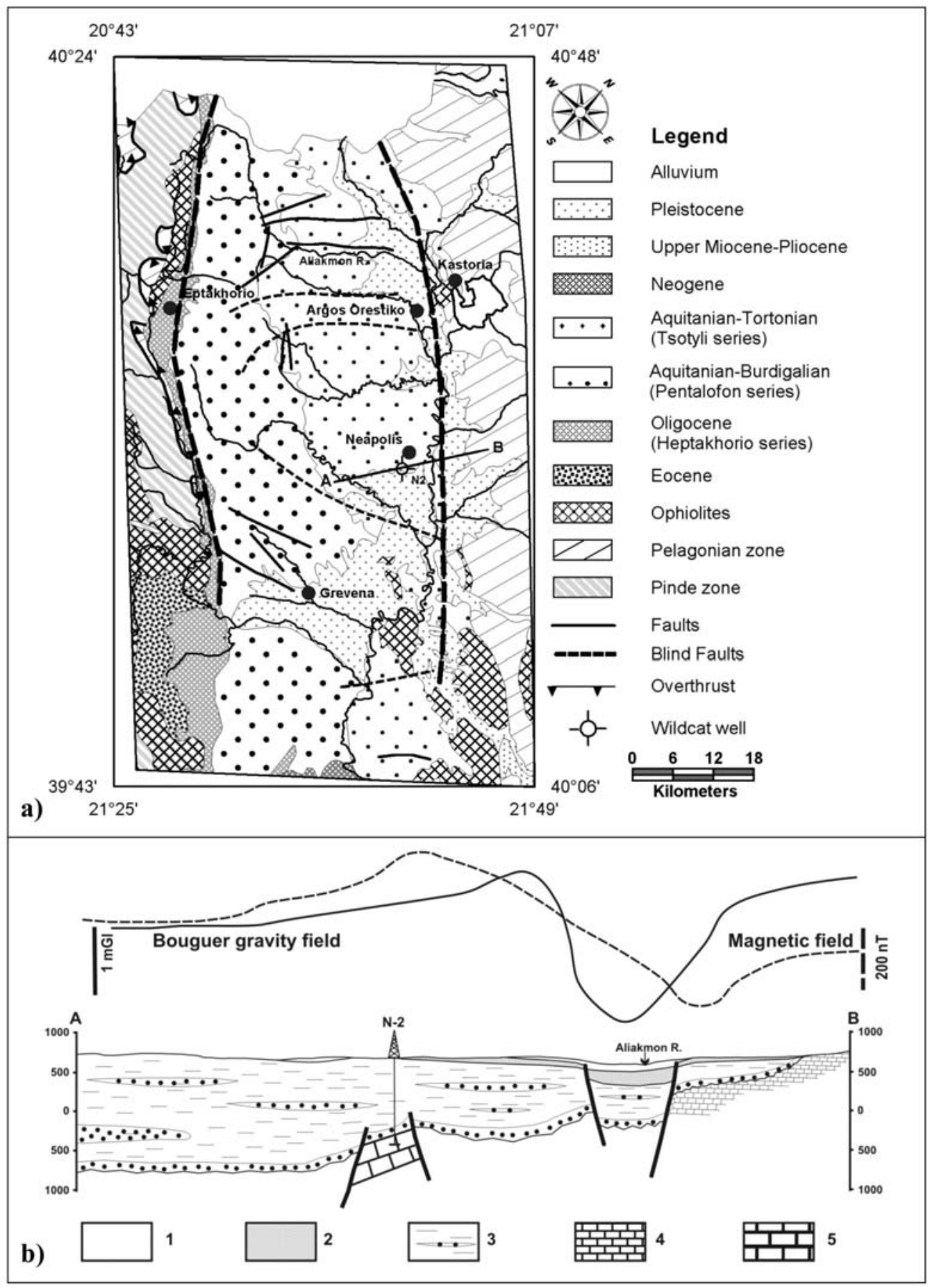

Fig. 1: (a) Map of the Meso-Hellenic Trench (modified after Geological Map of Greece, scale 1/500,000, IGME, 1983). (b) Geological section across the NE boundary; 1: Pleistocene, 2: Pliocene, 3: Marls \& conglomerates (Tsotyli series), 4: Pelagonian zone, 5: Pindos zone. 
that reactivated NE-SW to E-W trending normal faults, including the fault responsible for the 1995 Kozani-Grevena $(\mathrm{M}=6.5)$ devastating earthquake.

In terms of stress, the activation of the Kastoria fault trending NW-SE appears to be inconsistent with the Mid-Late Pleistocene kinematics of the broader area as well as with the slip-vector of the Grevena seismic fault as shown by the focal mechanism of the 1995 earthquake (Papazachos et al., 1995). Yet, the pitch of the slip-vector on a given fault plane depends not only on the orientation of the principal stress axes but also on a ratio $\mathrm{R}$ built on the differences of the principal stress values, such as $\mathrm{R}$ $=(\sigma 2-\sigma 1 / \sigma 3-\sigma 1)$. In an extensional tectonic regime, the azimuth of the slip-vector indicates the direction of extension only if the deviatoric stress $\sigma 2$ value is zero (i.e. $R=0.5$ ). It deviates from the extensional direction when the deviatoric stress $\sigma 2$ value is highly compressional $(\mathrm{R}<0.5)$ or extensional $(\mathrm{R}>0.5)$ (Mercier \& Lalechos, 1993). Thus, the dip-slip kinematics of the Kastoria fault with $\mathrm{R}>0.5$ is compatible with the existing stress field of the area.

\section{Seismicity characteristics of the Kastoria fault}

Analysis performed in the current study is based on the following recent catalogues: Papazachos et al., 2000 \& Papazachos et al., 2009 (completeness 1981-2009 M $\geq 4.0$ ); Papanastasiou et al., 2001 (completeness $\geq 4.5$ for the period 1950-2000); the current catalogue of IG-NOA for the period 19642009 (completeness $M \geq 3.5$ ) available on the site www.gein.noa.gr. Joint catalog was constructed for the under study area $39.95 \mathrm{~N} / 20.40 \mathrm{E}-40.95 \mathrm{~N} / 22.00 \mathrm{E}$; all the magnitudes in this catalogue were set equivalent to moment magnitude $\mathrm{M}_{\mathrm{W}}$, in the magnitude range $4.0 \leq \mathrm{M}<8.0$.

\subsection{Seismic activity}

As was mentioned above, three strong earthquakes, occurred in the past at distances than $30 \mathrm{~km}$ from Kastoria town $(1709, \mathrm{M}=6.0 ; 1812, \mathrm{M}=6.5$ and $1894, \mathrm{M}=6.1)$, could be related to the same seismogenic fault. Focal mechanism for this fault indicate normal motion on a northwest striking plane: strike $-160^{\circ} \mathrm{N}$, dip $-49^{\circ} \mathrm{W}$, rake $=-87^{\circ}($ Papazachos and Papazachou, 2003).

Distribution of earthquake epicentres in the under study region, shown on Figure $2 \mathrm{a}(\mathrm{M} \geq 4.0$, for the period of 1930-2009), defines some clusters of various shapes. Concentration of earthquakes at the NW corner of the area is apparently associated with the source of Konitsa earthquakes (1996, M = 5.2, 5.3 and 5.5). To the north, in Albania, a prominent concentration of epicentres is forming a N-S seismogenic fault, the source of 1919 earthquake $(M=6.3)$. Clusters observed at the NW corner appear to be associated with the N-S striking active faults (Aliaj \& Dushi, 2007). Relatively sparse, but, in some cases, linear distribution of epicentres, at the NE corner of the study region is forming the borders of Florina Basin, probably controlled by NW-SE active faults, as well as the location of some active faults of NE-SW direction (Mountrakis et al., 1995b). Most of the earthquakes observed at the SE part of the region, define a dense NE directed cluster that represents the 1995 Kozani-Grevena seismic excitation on the trending SW-NE Rimniou-Sarakinas fault zone (main shock $M=6.5$ ).

An area of concentrated seismicity in the centre of Figure 2a, which corresponds with the Greek part of Meso-Hellenic Trench (MHT), shows the relatively high density of epicentres to gravitate towards the NE border of MHT. The Albanian part of MHT, to which the 1960 earthquake source $(\mathrm{M}=6.3)$ is apparently attributed, has exhibited the highest concentration of epicentres in comparison to the Greek part. Moreover, the NE trending aseismic belt can be distinguished along the Greek-Albanian border, which separates the Albanian and Greek clusters of epicentres: no earthquakes have been recorded inside this, about 9-12 km width zone, across the MHT. This picture of 


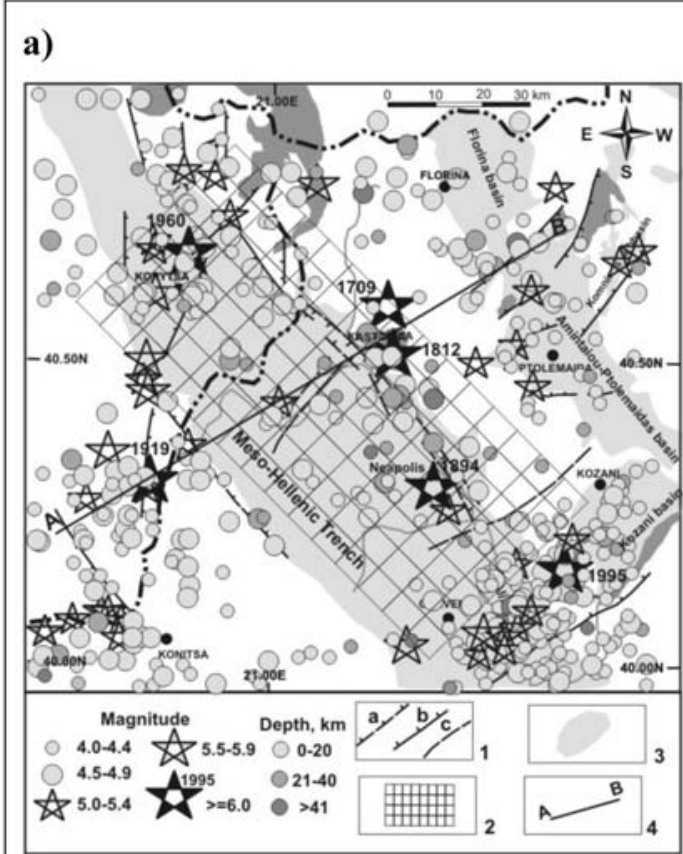

b)

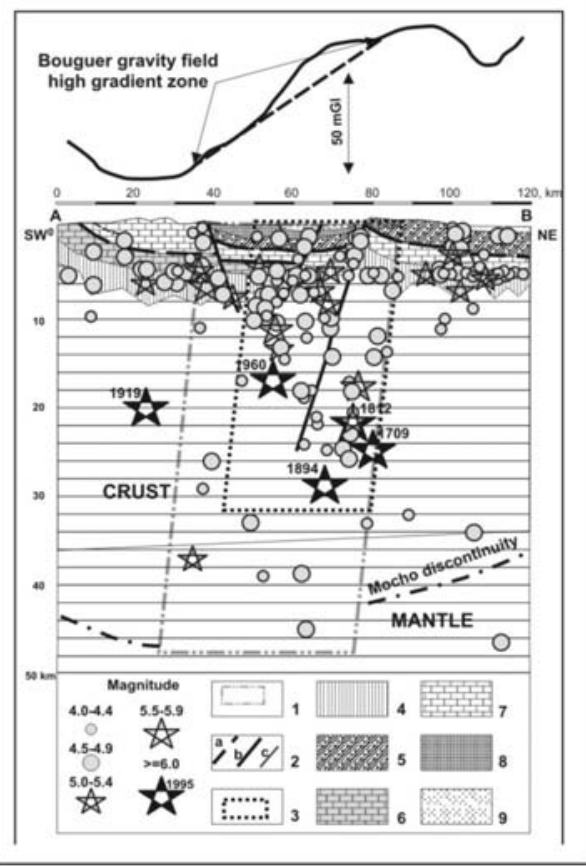

Fig. 2: (a) Distribution of earthquake epicentres vs active faults pattern in NW Greece (West Macedonia). 1: Active faults according to Mountrakis et al. (1995b) and Aliaj \& Dushi (2007); 2: Matrix used for epicentre density calculations; 3: Post-alpine basins; 4: Location of profile shown in fig. 2b. (b) Schematic geological-geophysical profile across the Meso-Hellenic Trench. 1: Contours of probable deep-seated crust-mantle structure; 2: Elements of rupture structure: a - nappes; active normal faults: b - main, bordering the MHT, c-secondary; 3 : Kastoria fault influence zone according to fault dip, penetration at depth and foci distribution; 4: Pre-alpine basement, 5: Pelagonian zone, 6: Gavrovo zone, 7: Pindos zone; Molassic fill of basins - 8: Mio-Pliocene, 9: Quaternary.

the epicentres distribution along the NE border of the MHT suggests: a) the existence of an active northwest trending seismogenic rupture zone, which is responsible for the seismicity of this area; b) segmentation of this rupture zone into Albanian and Greek segments with length of about 30 and $60 \mathrm{~km}$ respectively. The NW elongated belt of epicentres is also forming the SW border of MHT, as in Albania and in Greece, and probably proves that the rupture zone controlling the SW border of MHT is a seismogenic structure.

Analysis of the foci distribution along the schematic geological-geophysical cross-section (Fig 2b) shows that seismicity is involving all the crust, to a depth of approximately $40 \mathrm{~km}$. In the central part of the cross-section related to MHT, earthquakes occur at depths between 1 and $45 \mathrm{~km}$ and appear to define a steeply dipping crust-mantle structure beneath the MHT. In the gravity curve (Fig. 2b) this structure is characterized by width zone of Bouguer field high gradient, as it is characteristic for that kind of deep-seated structures (Khesin et al., 1982). To NE and to SW of MHT, the thickness of seismogenic layer does not depasse $12 \mathrm{~km}$. Generally, we observe that outside of MHT zone, the foci are mostly concentrated on faults that border the recent basins, as well as along some crustal discontinuities, as Figure 2b displays. 


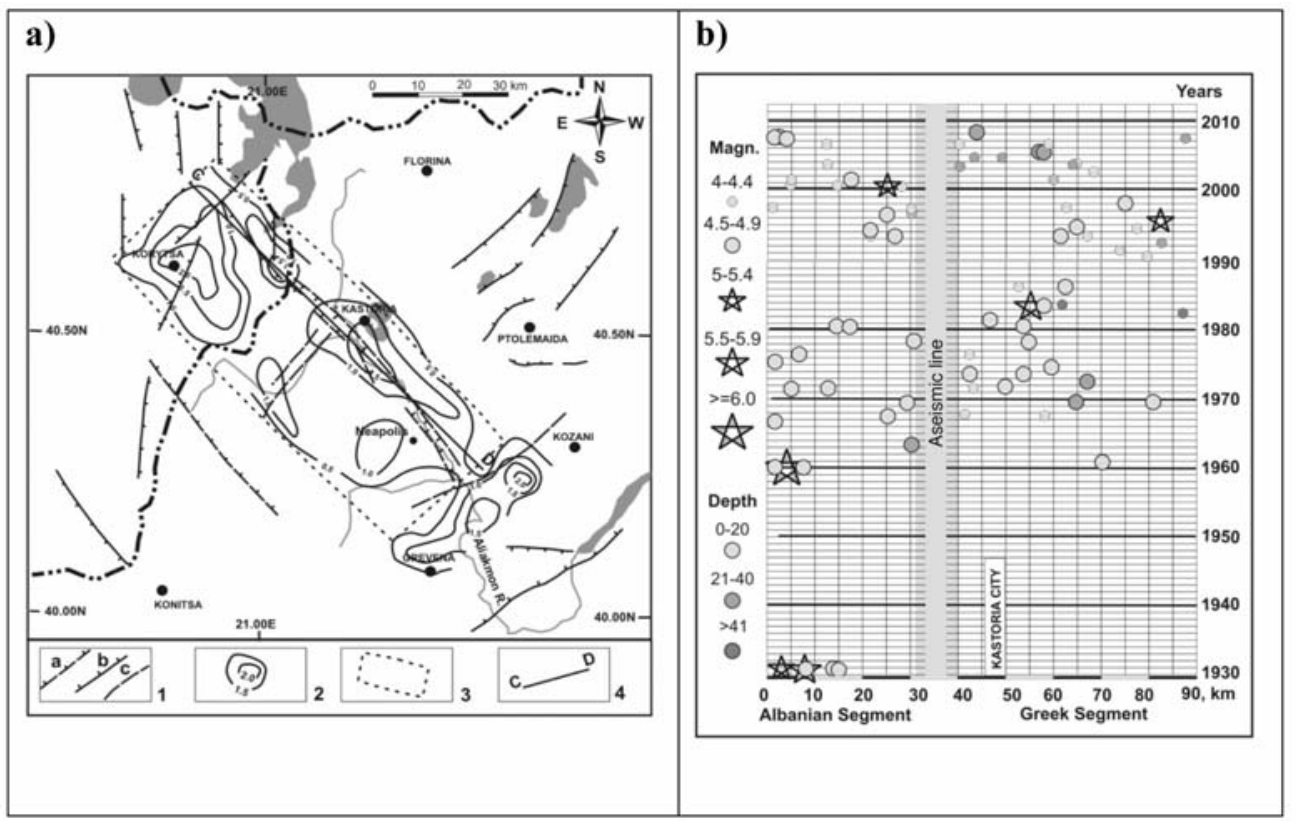

Fig. 3: (a) Density of earthquake epicentres along the Kastoria fault. 1: Active faults according to Mountrakis et al. (1995b) and Aliaj \& Dushi (2007); normal faults (barbs towards the subsided block): a- probable, bmapped, c - faults with undetermined kinematics. 2: Contours of epicentre density, 3: Kastoria fault influence zone, 4: Location of NW-SE profile shown in Fig. $3 \mathrm{~b}$.

\subsection{Fault Influence Zone}

For quantification of the fault recurrence model, we attempted to define earthquake clusters appearing to belong to the Kastoria fault at the NE border of MHT from those corresponding to the surrounding structures. To evaluate the seismic activity along the fault objectively and quantitatively, a simple method has been proposed by Watanabe et al (2006). For each surface fault trace - in our case the area of probable "blind" fault trace - narrow zones $\mathrm{Zi}$ are made on the surface, dividing the distance from the fault trace in fixed intervals (i.e. in $\mathrm{km}$ ). For each $\mathrm{Zi}$, the number of epicentres $\mathrm{Ni}$ is counted. Then, the density of earthquake number $\mathrm{DNi}$, can be expressed as $\mathrm{DNi}=\mathrm{Ni} /\left(\mathrm{Si}{ }^{*} \mathrm{P}\right)$, where $\mathrm{Si}$ is the area of zone $\mathrm{Zi}$, and $\mathrm{P}$ is the time interval of analysis. DNi generally decreases with the distance from the fault. Thus, the distance where DNi reaches the background level is defined as the fault influence distance FID and the area countered by FIDs can be defined as Fault Influence Zone (FIZ). Because of the lack of evidences about the Kastoria fault surface trace, the grid used in the current study is represented by covering the MHT, NW oriented matrix, of $\sim 50 \mathrm{~km} * 100 \mathrm{~km}$ dimension, with similarly elongated narrow cells of size $\sim 6 \mathrm{~km} * 7 \mathrm{~km}$. For more understandable presentation, the DNi value was calculated as:

$\mathrm{DNi}=\mathrm{Ni} /\left(\mathrm{Si}^{*} \mathrm{P}\right) * 100 \%$.

For background level the value 0.5 has been chosen, which means one epicentre inside the cell. The result displayed in the Figure $3 \mathrm{a}$, shows more clearly the faults length and the segmentation of the seismogenic rupture zone along the NE board of MHT; it also allows the contouring of the Fault Influence Zone at surface. The geometry of FIZ defined by seismicity data is in good agreement with the 
geometric parameters of FIZ, which were determined, using the fault geometry characteristics, such as fault orientation, length, probable dip angle, penetration at depth (as it can be also seen on Fig. 2b).

It has to be noted that the whole set of epicentres located in the area where the 1995 Kozani earthquake occurred, has not been taken into consideration in the assessment of Kastoria fault seismicity rates.

\subsection{Seismic cycle of the fault}

The seismic activity cycle along an active fault can be classified in 4 stages, namely the main shock stage, the aftershock stage, the calm stage and the pre-seismic stage (Mogi, 1985). Period of observations for modern seismology is about one hundred years, and it is only a small portion of a cycle that is as long as hundreds to thousands of years. Therefore, it is difficult to recognize the portion of the seismicity cycle corresponding to the current seismic activity. Since there are large variations of recurrence times for each active fault, the concept of Lapsed Rate has been introduced (Itaba and Watanabe, 2005). To assess the Lapsed Rate of an active fault, we have to know Lapsed Time (LT), which is the time interval from the latest major earthquake, occurred on the fault as well as the Recurrence Time (RT), which is the mean recurrence interval of strong events (or events with particular magnitude of interest) for the fault. Therefore, LR is defined from RT and LT of a fault as:

$\mathrm{LR}=(\mathrm{LT} / \mathrm{RT}) * 100[\%]$

Considering the study of the Kastoria fault (Greek segment) the LR values have been determined for $M \geq 6.0$ earthquakes occurred since 1709; there are 3 events in about 300 years, i.e. 100-year RT events with magnitude $M=6.0-6.5$. The calculation performed shows $L R=115 \%$, which allows us to assume that the active Kastoria fault could be in a preparatory stage (pre-seismic according to Mogi, 1985) of the fault seismic cycle.

The space-time distribution of the earthquakes along the Kastoria fault zone (Fig. 3b) displays the fault recent seismic activity. On the Greek segment three periods of activation may be observed. The first occurred the 70's - 80's (17 events with $M=4.2-4.6$ ). The second in the 90's (16 events with $M=4.0-4.7)$, appears to be the consequence of the 1995 Kozani earthquake $(M=6.5)$; it was closed with an $M=5.0$ event. The third period which has started in 2002 mostly with events at depth $>20 \mathrm{~km}$ is still in progress (to date there are 13 events with magnitude $M=4.0-4.7)$. It is notable, that each time, during the seismic excitations, the activity has been concentrated at different halves of the Greek segment of the Kastoria fault: during the first period at the NW part of the segment; during the second period at the SE part of the segment and during the period of the last 7 years at the NW part of the segment again (Fig. 3b). The Albanian segment behaves almost in the same way as the Greek one. It is apparently characteristic for solitary fault zones: activation in 90 's with main event $\mathrm{M}=5.0$ in 2001, framed by foreshock and aftershock sequences at the SE part of the segment, then continuous in the 2000's at the NW part of the Albanian segment.

According to Toda, 2002 (in Itaba \& Watanabe), the following tendency has been found from the sequences of recent micro and moderate sized earthquake activity on a fault: "When the lapsed time from the most recent event is close to or larger than the recurrence time, seismic activity is comparatively or locally high". Concerning the M 6.0-6.2 event with 100-year recurrence time (the worst scenario), today's seismic activity of the Greek segment of the Kastoria fault looks to be consistent with the pre-seismic activation stage of the fault.

\section{Probabilistic Seismic Hazard Assessment (PSHA)}

Analysis of Seismic Hazard that can be due to the Kastoria fault is based on probabilistic concepts, 
Table 1.

\begin{tabular}{|c|c|c|c|c|c|c|c|}
\hline & \multicolumn{2}{|c|}{ Length, km } & \multirow{2}{*}{ Dip } & \multirow{2}{*}{$M \max$} & \multirow{2}{*}{ Mmin } & \multirow{2}{*}{$\begin{array}{c}\text { Seismicity rate, } \\
\geq \text { Mmin }\end{array}$} & \multirow{2}{*}{ b } \\
\hline & Sur-face & Subsurface & & & & & \\
\hline $\begin{array}{c}\text { Kastoria } \\
\text { Normal Fault, } \\
\text { Greek segment }\end{array}$ & $?$ & 60 & $\sim 60^{\circ} \mathrm{SW}$ & 7.0 & 4.0 & 2.05 & 1.08 \\
\hline
\end{tabular}

which allow incorporation of both geological and seismological data. The Cornell-McGuire method (Cornell, 1968; McGuire, 1995, 2004) has proven particularly well suited to calculate expected ground motions for a wide range of seismotectonic environments. The methodology has been realised in EZ-FRISK PC Programme (Risk Engineering, 2005).

\subsection{PSHA methodology}

Calculation of hazard requires specification of three inputs in EZ F-RISK programme: a) Source geometry, which is the geographic description of the seismic sources. b) Seismicity, which is the rate of earthquake occurrence in particular seismic source and c) Attenuation Equations, which are the relationships that allow the appraisal of ground motion parameters at the site as a function of earthquake magnitude, source-to-site distance and soil conditions at the site.

A seismic source, in our case, is a tectonic fault. Geometry and seismicity parameters of the Kastoria fault, as input for PSH calculations, are shown on the Table 1. Seismic potential of the fault (Mmax) was assessed using Wells and Coppersmith (1994) functions.

The time-independent recurrence model for the Kastoria fault source is based on the observed frequency of occurrence of instrumental seismicity within the above defined Fault Influence Zone. For ground motion parameter calculations, the attenuation equation proposed by Ambraseys et al (1996) for rock conditions was used.

\subsection{Results of PSH calculations}

The calculations of Kastoria fault activity rates show, that magnitude of event with about 100-year recurrence time, derived using seismicity parameters of the fault, is about 6.1, which is in agreement with the magnitudes of the three events occurred at the fault during the last 300 years (Fig. 4a).

Total Seismic Hazard Curve, a plot of annual probability of exceedance versus a specified ground motion parameter, displaying the 5\% damped values of spectral acceleration $(\mathrm{Sa})$ for spectral period $\mathrm{T}=0.3 \mathrm{sec}$, for horizontal component of motion on bedrock, is shown on Figure $4 \mathrm{~b}$.

\section{Conclusions}

The mapping of the Kastoria "blind" fault at the NE border of Meso-Hellenic Trench was performed by using geological data as well as the results of geophysical and seismological observations. The location of the fault zone was defined by the distribution of NW-SE elongated Quaternary basins developed along the bed of Aliakmon River. The existence of such narrow basins below the Aliakmon riverbed is proven by the gravity and magnetic data collected by the Institut Français du Pétrole (1966). The correspondence of elongated gravity minima with elongated in the same direction mag- 


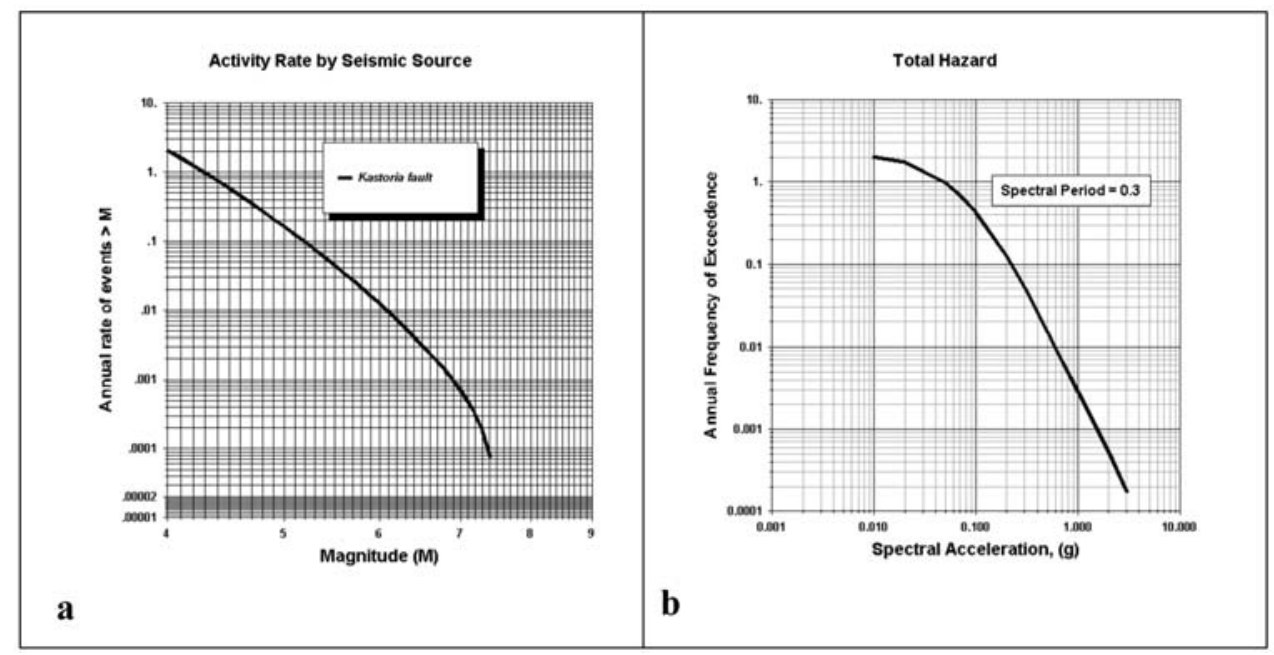

Fig. 4: (a): Activity rates of the Kastoria fault and (b): Total Hazard Curve calculated for bedrock conditions from fault source "Kastoria Fault" at the site "Kastoria town" (Kastoria Strong Motion Station of ITSAK, KAS1, 40.52N, 21.26E, limestone, dolomite limestone).

netic maxima shows the existence of narrow grabens (1-2 km width) filled with Neogene - Quaternary deposits that are characterised by relatively increased magnetic susceptibility (see Table 1 in Metaxas et al, 2001), attributed to effects of ophiolite erosion materials involved in the sedimentation.

The picture of the earthquake epicentre distribution in the area of MHT and particularly along its NE border, proves the existence of an active northwest trending seismogenic rupture zone segmented into two segments (Albanian and Greek) with length of about 30 and $60 \mathrm{~km}$ respectively, that are separated by NE trending, 9-12 km wide aseismic belt along the Greek-Albanian border.

The Lapsed Rate of the Kastoria fault Greek segment, calculated for three $M \geq 6.0$ earthquakes occurred since 1709 (100-year Recurrence Time events), shows value of $115 \%$, which allows us to assume that the active Kastoria fault could be in a preparatory stage of the fault seismic cycle.

The result of PSHA shows that the calculated magnitude for event with 100-year recurrence time is $\sim 6.1$, which corresponds to the magnitudes of three events, occurred at the fault during the last 300 years. According to Slemmons \& dePolo (1986) empirical diagram, the active fault, that gives event of magnitude $\sim 6.1$ with recurrence time $\sim 100$ years, is characterised by a slip rate of $3 \mathrm{~mm} / \mathrm{yr}$. This value corresponds to that of the vertical movements which are shown by the thicknesses of the Holocene deposits (30 - $40 \mathrm{~m}$. for the last 10,000 years) along the Greek segment of the blind Kastoria fault.

As the calculated Hazard Curve is showing, the event of that range could give ground shaking in the Kastoria town of the order of $0.625 \mathrm{~g}$ at the spectral period of $0.3 \mathrm{sec}$.

\section{References}

Aliaj, S., \& Dushi, E., 2007. Seismogenic Models for Albania: Overview of Relevant Data. First Workshop for the NATO Science for Peace, Project No 983054: "Harmonization of Seismic Hazard Maps for the Western Balkan Countries". Ljubliana, Slovenia, 9 November 2007 (Presentation).

Ambraseys, N.N., Simpson, K.A., and Bommer, J.J., 1996. "Prediction of Horizontal Response Spectra 
in Europe”, Earthquake Engineering and Structural Dynamics, Vol.25, p. 371-400.

Bizon, G., Bizon, J.-J., Lalechos, N., Savoyat, E., 1968. Présence d'Éocène transgressif en Thessalie. Incidences sur la paléogéographie régionale. Bull. Soc. Géol. de France (7), X, p. 36-38

Boschi, E., Giardini, D., Pantosti, D., Valensise, G., Arrowsmith, R., Basham, P., Burgmann, R., Crone, A., Hull, A., McGuire, R., Schwarts, D., Sieh, K., Ward, S., and Yeats, R., 1996. New trends in active faulting studies for seismic hazard assessment. ANNALI DI GEOFISICA, XXXIX, 1301-1307.

Cornell, C.A., 1968. "Engineering seismic risk analysis", Bull. Seism. Soc. Am., 58, 5, 1503-1606.

Doutsos, T., Koukouvelas, I., Zelilidis, A., Kontopoulos N., 1994. Intracontinental wedging and postorogenic collapse in the Mesohellenic Trough. Geologische Rundshau, 83, 257-275.

Institut Français du Pétrole / Branche Recherche et Exploitation du Pétrole 1966. Etude des bassins de Grevena - Thessalie. Rapport pour le Ministère de l'Industrie, Direction Générale des Mines, Grèce.

Itaba, S., and Watanabe, K., 2005. Seismicity cycle and large earthquakes. Pp.4. On-line: http//www.ism.ac.jp/ ogata/Statsei4/abstr/Itaba. pdf

Itaba, S. and Watanabe, K. Seismic activity before and after a large earthquake in seismicity cycle. On line: http://www.rcep.dpri.kyoto-u.ac.jp/ itaba

Itaba, S., Watanabe, K., Nishida, R., Noguchi, T. Change of seismic activity in the cycle of a large earthquake. On-line: http://www.rcep.dpri.kyoto-u.ac.jp/ itaba

Khesin, B., Metaxas, Ch., Alexeev, V., 1982. About the geological nature of large-scale gravity anomaly Taliss-Vandam (On the problem of crustal model of $15 \mathrm{~km}$ super-deep well SG-1 in Azerbaijan). VINTI Publishers, No 3680-82, Moscow, 30 pp. (In Russian).

McGuire, R., 1995. Probabilistic seismic hazard analysis and design earthquakes closing the loop. Bull. Seism. Soc. Am., 85, 5, 1275-1284.

McGuire, R., 2004. Seismic Hazard and Risk Analysis. EERI Monograph MNO-10. Earthq. Eng. Res. Inst., Oakland, Ca.

Mercier, J-L and Lalechos, S., 1993. The Middle-Late Pleistocene NW-SE extension in Southern Peloponnesus and the kinematics of the seismic fault of the 1986 Kalamata earthquake (Greece). Proceedings of the 2nd Congress of the Hellenic Geophysical Union, Florina, 5-7 May 1993, (Seismology), 586-594.

Mercier, J-L., Sorel, D., Lalechos, S., Keraudren B., 1993. The tectonic regimes along the convergent border of the Aegean arc from the late Miocene to the present; southern Peloponnesus as an example. NATO advanced research workshop on Recent evolution and seismicity of the Mediterranean region. Erice, Italy, Sept. 18-27, 1992 (In: Recent evolution and seismicity of the Mediterranean region, NATO ASI Series. Series C: Mathematical and Physical Sciences, 402, 141-160, 1993. Boschi-E (editor); Mantovani-E (editor); Morelli-A (editor).

Metaxas, C., Angelopoulos, A., Lalechos, S., Foundoulis, D., 2001. Deep tectonic structure of Northwestern Attica, Greece: Geodynamic Pattern of Athens Earthquake. Proceedings of the $9^{\text {th }}$ International Congress, Athens, September 2001. Bulletin of the Geol. Soc. of Greece, XXXIV/1, 259-265.

Mogi, K., 1985. Earthquake Prediction. ACADEMIC PRESS. HBJ Publishers, 382.

Mountrakis, D., Pavlides, S., Zouros, N., Chatzipetros, A., Kostopoulos, D., 1995a. The 13 May 1995 western Macedonia (Greece) earthquake. Preliminary results on the seismic fault geometry and kinematics. XV Congress of the Carpatho-Balkan Geological Association, September 17-20, 1995, Athens, Greece, 11.

Mountrakis, D. et al., 1995b. Map of the active faults of Greece, Macedonia area, scale 1:300 000, Thessaloniki University.

Papanastassiou, D., Latoussakis, J., Stavrakakis, J., 2001. A Revised Catalogue of Earthquakes in the 
Broader Area of Greece for the period 1950-2000. Proceed. of the $9^{\text {th }}$ International Congress, Athens, September 2001. Bulletin of the Geol. Soc. of Greece, XXXIV/4, 1563-1566

Papazachos B.C, Panagiotopoulos, D.G, Scordilis, E.M, Karakaisis, G.F., Papaioannou, Ch.A., Karakostas, B.G., Papadimitriou, E.E., Kiratzi, A.A., Hatzidimitriou, P.M., Leventakis, G.N., Voidomatis, Ph.S., Peftitselis, K.J., Tsapanos, T.M., 1995. Focal properties of the 13 May 1995 large (Ms $=6.6$ ) earthquake in the Kozani area (North Greece). XV Congress of the Carpatho-Balkan Geological Association, September 17-20, 1995, Athens, Greece, 13.

Papazachos B. and Papazachou, K., 2003. Earthquakes of Greece. ZITI Publishers,Thessaloniki, 2003, 286. (In Greek).

Papazachos, B.C., Comninakis, P.E., Karakaisis, G.F., Karakostas, B.G., Papaioannou, Ch.A., Papazachos, C.B. and Scordilis, E.M., 2000. A catalogue of earthquakes in Greece and surrounding area for the period 550BC-1999. Publ. Geophys. Laboratory, University of Thessaloniki, 1, 333.

Papazachos, B.C., Comninakis, P.E., Scordilis, E.M., Karakaisis, G.F. and Papazachos, C.B., 2009. A catalogue of earthquakes in the Mediterranean and surrounding area for the period $1901-2008$. Publ. Geophys. Laboratory, University of Thessaloniki.

Papanikolaou, D.J., Lekkas, E.L., Mariolakos, I.D., Mirkou, R.M., 1988. Contribution to the geodynamic evolution of the Mesohellenic basin. Bulletin of the Geol. Soc. of Greece, XX, 17-36.

Risk Engineering, 2005. EZ-RISK, Software for In-depth Seismic Hazard Analysis. Version 7.01, 272.

Slemmons, D.B. and dePolo, C.M., 1986. Evaluation of active faulting and associated hazards: in Wallace, R.E. (ed.), Studies in Geophysics, Active Tectonics, National Academy Press, 266.

Vergély P., 1984. Tectonique des ophiolites dans les hellénides internes - Conséquences sur l'évolution des régions téthysiennes occidentales. Thèse, Université de Paris-Sud.

Watanabe, K., Itaba, S., Mori, J., Nishida, R., 2006. Quantitative evaluation of seismic activity around active faults and a general seismicity cycle of the fault. AOGS 2006, 794/1202

Wells, D., and Coppersmith, J., 1994. New Empirical Relationships among Magnitude, Rupture Length, Rupture Wight, Rupture Area, and Surface Displacement. Bulletin of the Seismological Society of America, 84, 974-1002. 